\title{
Practices of Comparing in Eighteenth-Century Grammars of English
}

Göran Wolf

\section{Introduction}

The eighteenth century did not contribute comprehensive language-internal developments to the history of the English language (see Romaine 1998: 1, Görlach 2001: 8, or Hickey 2010: 2). Yet, the eighteenth century is a remarkable period in the history of English because it is embedded within a longer stretch of time at the beginning of which "English was still a minor language in Europe; by the end it had become one of the major languages of the world" (Bloomfield/Newmark 1963:289). This transformation, however, is not the only language-external event that marks the period as crucial for the history of the English language. More developments took place and two important ones are vividly captured by the titles of chapters in the early editions of well-known text books: "The Appeal to Authority, 1650-1800" (Baugh 1959) and "The Problem of Correctness and Good Usage: 1600-1850" (Bloomfield/Newmark 1963). The place in which language usage, correctness and authority were negotiated with regard to the English language throughout the (long) eighteenth century were grammars of English. It is these grammars and also related works that constitute the source for what is presented here.

Grammars of English are a remarkable group of texts in the eighteenth century, since their rate of publication experienced a considerable increase (Michael 1970: 2; also see Alston 1965). They have been subjected to extensive research for decades and studies show that they are multi-faceted sources. As such, eighteenth-century grammars of English (and related works) can also contribute to a detailed understanding of eighteenth-century practices of comparing. Indeed, the works appear to exhibit instances of intra- and intercultural comparison. The cases of intracultural comparison seem to serve language description and language prescription, the cases of intercultural com- 
parison seem to support language emancipation and arguments related to the self-assertion of the English language. In order to demonstrate this, the chapter on hand will proceed as follows. The next subchapter introduces, explains and illustrates a fundamental concept which helps to position the grammars within their immediate context, i.e., the history of grammaticography, as well as to relate the presented instances of comparison to the methodological repertoire found in the grammars. The third subchapter is the informative core of this paper. It gives a qualitative analysis of selected passages from both well-known and lesser-known titles of eighteenth-century grammaticography. Accordingly, noteworthy aspects are highlighted and summarized in this paper's conclusion.

\section{Eighteenth-Century Grammars of English as 'Discourse Tradition'}

Before I turn to the notion of 'discourse tradition' and its applicability with regard to (eighteenth-century) grammaticography, a brief note on the selection of sources and their context shall be permitted. In this contribution, I present findings that relate to the research carried out for my dissertation (Wolf 2011). For the latter I studied the grammars of 112 authors covering the period from 1600 to 1900 . Obviously, the selection presented here is restricted to eighteenth-century authors. ${ }^{1}$ The selection still includes a) widely known works, such as Robert Lowth's A Short Introduction to English Grammar (1762), Lindley Murray's English Grammar (1795), or Joseph Priestley's The Rudiments of English Grammar (1761), that, as will be indicated further below, have been the subject of very thorough scholarly examination, b) lesser-known pieces, such as James Buchanan's The British Grammar (1762), which have gained some attention in scholarship (see e.g. Emsley 1933), and c) almost unknown specimens that are named and listed in Alston's eminent bibliography (1965), but whose scholarly consideration does not go much beyond that.

1 The number of grammars and related works to which I point because of their practices of comparison is still smaller. This, however, does not translate into the statement that the presented cases of comparison are the only ones observable in the texts. The presented instances in which comparisons form substantial parts of the methodological and conceptual make-up of the selected texts are instances that have made a lasting impression on the present author whose main examination of the primary texts took place a decade ago. 
Eighteenth-century grammars of the English language have been studied and described in full detail. The works themselves were without doubt normative and, therefore, their prescriptivism essential in the development of standard English (e.g. Beal 2004, Tieken-Boon van Ostade 2006 and Beal 2010). Their authors, motivations and approaches as well as their general context have also been subjected to close scrutiny (see Tieken-Boon van Ostade 2008). As far as research interest is concerned, a few grammarians certainly stand out, most notably Robert Lowth, Lindley Murray, and Joseph Priestley. The studies of their lives and works do also include investigations into the personal background of the works as well as their conceptual contexts (e.g. Fensde Zeeuw 2011, Hodson 2006, Rivers/Wykes 2008, Straaijer 2011, Tieken-Boon van Ostade 1996, Tieken-Boon van Ostade 1997, Tieken-Boon van Ostade 2010 and Tieken-Boon van Ostade 2011).

One aspect that has been stipulating research and that is almost virtually present in all research up to the present is the interrelationship of the grammars themselves (e.g. Leonard 1929, Vorlat 1964, Robins 1986, Sundby/Bjørge/Haugland 1991, or Tieken-Boon van Ostade 2008). Whereas there are many characteristics that make us conceive of eighteenth-century grammars as a coherent group of texts, it is their mutual interference, or interdependence, that truly displays the grammarians as a group of interrelated authors. The notion of 'discourse community' appears to be applicable in this regard. That this is a successful undertaking has been shown by Richard Watts, who convincingly conceptualized grammarians as a group of authors who share common goals, expertise, and communicative means (see Watts 1995 and 2008). Still, if we wish to perceive those authors as a 'discourse community', we might want to consider the discourse itself. $^{2}$

In this discourse - it does not only take place in the grammatical treatises proper, but also quite frequently in their prefaces, dedications, and footnotes -, the members of the discourse community of grammarians exchange opinions and experiences. For example, they acknowledge each other expressis verbis. In the preface of An Easy English Grammar, Alexander Murray, for instance, places himself into that discourse:

I must acknowledge, that it is not the want of English Grammars, that makes me trouble the Public with a new one. So far from this being the case, I have

2 Of course, all of the notions related to 'discourse' are ultimately informed by Michel Foucault's 1971 work. 
thirty different books on the subject lying about me [...]. Yet I am not singular in opinion, that something is still necessary, though perhaps, not so much with respect to the matter as the manner of forming the most useful schoolbook [...]. (Murray 1787: iii)

Considering this example of mutual referencing, it is clear that the discourse of eighteenth-century grammarians is a conscious one. If an author states in his work that his grammar cannot sufficiently replace preceding works and that such an accomplishment can only be achieved by authors such as Robert Lowth or Samuel Johnson (Bicknell 1790: xii), we deal with another exemplary manifestation of this discourse. Because of such observations, I have suggested that grammars be viewed as a 'discourse tradition' (Wolf 2011). Since this concept is still not widely known in English linguistics, the term and its application require further explanation. First suggested by Brigitte SchliebenLange (1983), the concept of 'discourse tradition' has been elaborated by Peter Koch (1997) and by Wulf Oesterreicher (1997). Essentially, the concept is an addition to Coseriu's threefold concept of language (see Coseriu 1988) in which the universal level is speech in the sense of 'ability to speak', the historical level is the individual language, and the individual level is the speech act (see Koch 1997: 44). 'Discourse tradition' is an addition, because Koch doubles the historical level, and 'discourse tradition' is the concept that is able to cross boundaries of individual languages. The latter is crucial if applied within the context of grammaticography. In that regard, it is also noteworthy that the concept of 'discourse tradition' draws upon an essential analogy: If there are 'rules' in languages, there are rules in discourse traditions, too (see Koch 1997: 45). These rules - and this is where the concept links up with Watts' 'discourse community' - are inherited, conserved and communicated by cultural communities such as professional, literary, or political groups (see Koch 1997: 49).

Some rules, or discourse conventions, of the specific discourse tradition of 'grammar-writing' are: 1) the didactic way of proceeding from smaller to larger linguistic units, i.e., from letters/sounds via syllables and individual words to sentences, 2) the frequent imitation of classroom dialogue by writing in question-and-answer mode, and 3) the rigid structure of topical chapters proceeding from definitions via discussions to exemplifications. Another very specific 'discourse rule' in (eighteenth-century) grammars of English is employing definitions to clarify the usage of technical terms or to introduce new, difficult, or arcane concepts. Containing numerous definitions, eighteenthcentury grammars display a high degree of uniformity and Ian Michael has 
hinted at that phenomenon in his seminal work on grammatical categories (1970). He specifically drew attention to uniformity with regard to the very foundational definition of the term 'grammar' itself. He said that, if a definition is given - if not, grammarians took the definition as preconditional -, it is presented in form of the "conventional formula", which generally, i.e., across centuries until the dawn of philology, reads grammar as "the art of speaking and writing correctly" (Michael 1970: 189). To illustrate this point, an exemplary selection of eighteenth-century definitions is given here. The list is not exhaustive. The definitions are given without original, yet with added emphases:

1) Grammar is the Knowledge or Art of Expressing our Thoughts in Words join'd together in Sentences according to the Use, Form and Propriety of every Tongue either in Speaking or Writing. (Gildon/Brightland 1711: i)

2) Grammar is the Art of Speaking rightly. (Greenwood 1711: 34)

3) Grammar is an Art, which teacheth the way of writing and speaking truly and properly. (Maittaire 1712: 1)

4) Grammar is the Art of Speaking and Writing truly and properly. (Greenwood 1737: 2); English Grammar is the Art of speaking and writing English truly and properly. (ibid.: 3)

5) Question. What doth the English Grammar teach? Answer. To speak, or write English truly and properly. (A New English Grammar 1746: 1)

6) Grammar is the Art of Speaking and Writing truly and properly. (Gough 1760: 1)

7) Grammar is the art of using words properly. (Priestley 1761: 1)

8) Grammar is the Art of expressing the Relations of Words in Construction, with due Quantity in Speaking, and Orthography in Writing. Hence it is, that a Grammar of whatever Language, shews the Art of Speaking and Writing that Language well. What does the English Grammar teach? The English Grammar teaches to speak and write the English language rightly. (Buchanan 1762: 1f.)

9) Grammar is the Art of rightly expressing our thoughts by words. (Lowth 1762: 1)

10) Grammar is the art of writing or speaking any language correctly [...]. English Grammar is the art of writing or speaking the English language properly. (Burn 1766: 19) 
11) Grammar is the Art of speaking and writing with Propriety. (Hodgson 1770: 1)

12) A New Grammar of the English Language; or An Easy Introduction to the Art of Speaking and Writing English with Propriety and Correctness (Fenning 1771: front matter)

13) Grammar is the Art of speaking or writing any Language rightly; as Hebrew, Greek, Latin, English, \&c. M. What is English Grammar? S. The Art of speaking or writing the English Tongue. (Metcalfe 1771: 1)

14) Grammar is the Art of Speaking, or Writing a Language properly. English Grammar is the Art of Speaking or Writing the English Language properly. (Raine 1771: 1)

15) Grammar is the art of speaking and writing correctly. Latin or English Grammar is the art of speaking and writing the Latin or the English language correctly. (Adam 1772: 1)

16) Grammar is the Art of expressing our Thoughts with Propriety, either in Speaking or Writing. (Ward 1777: 1)

17) Question. What is Grammar? Answer. The Art of rightly expressing our Thoughts by Words. (Corbet 1784: 9)

18) Grammar in general, may be denominated an art of speaking and writing with propriety. (A., M. 1785: 5)

19) Grammar is the art of speaking and writing any language with propriety. English Grammar teaches to speak and write the English Language properly. (Murray 1787: 1)

20) Grammar teaches the proper use of words, and enables us to communicate our thoughts with perspicuity. (Brittain 1788: Introduction [1])

21) Grammar, is the Art of speaking, and writing, any Language properly, and correctly. (Chown 1788: 5)

22) Grammar is that art which teaches due and proper arrangement, and also the choice of words, in order to express our thoughts by the mouth, or in writing. (Bicknell 1790: 1)

23) Grammar is the Science of using Words correctly. (Francis 1790: 11)

24) What is English Grammar? The art of speaking and writing the English language correctly, according to rules and general practice. (Webster 1790: 5)

25) Grammar, in general, teaches us the art of expressing our thoughts with propriety; therefore the English Grammar instructs us how to convey our thoughts in proper English. (Hornsey 1793: 13) 
26) Grammar is the art of speaking or writing a language properly. (A Short English Grammar 1794: 1)

27) English Grammar is the art of speaking and writing the English language with propriety. (Murray 1795: 1)

28) The English Grammar is the Art of speaking and writing the English Language with Correctness and Propriety. (Postlethwaite 1795: 1)

29) English Grammar is the art of speaking or writing the English language properly. (Rhodes 1795: 7)

30) Grammar is the Art of speaking, or of writing, a Language with propriety, and the intent of Language is to communicate our thoughts to others. (Coar 1796: 1)

31) Grammar is the art of speaking and writing correctly. (Bullen 1797: 1)

32) Grammar is the art of speaking and writing with propriety. (Kitson 1798: 1)

33) Grammar is the art of speaking and writing a language with propriety. (Gardiner 1799: 1)

34) Grammar is the art of speaking and writing with propriety. (Eves 1800: 1)

With or without the added emphases, the list shows that in the eighteenth century the formula is almost always: 'grammar is the art of speaking and writing properly/with propriety'. Of course, 'properly' and 'with propriety' in the examples above relate to Michael's 'correctly'. Still, it is not the same proposition. Proper language use is not that language use which is correct because it corresponds to all available and grammatically correct patterns found in language. Proper language use is that language use which is proclaimed as correct because it is the language use of those who behave properly, i.e., in a manner that is approved and accepted by the social and educational elite. This specific reference to propriety is what signals prescriptiveness in the definitions; the preferred language use is charged with the ideology of propriety just described. That, however, is typical of eighteenth-century grammars and it is normal in a century in which empirical approaches to language(s) had not yet been established. The link between propriety and preferable language patterns against the background of uniform definitions is also relevant for what is delineated in the next subchapter. 


\section{Instances of Practices of Comparing}

Before I foreground the selected practices of comparison as they can be witnessed in the grammars, I should like to comment very briefly on the notion of 'practices of comparing'. I do not subscribe to any but the fundamental meaning of the lexeme comparison: 'the action, or an act, of comparing, likening, or representing as similar' (see OED 2020).

Practices of comparing are fundamental in many grammars and there is one specific form that appears to be the base prescriptiveness, the predominant quality in most of them. This practice likens wished-for language usage to appropriate social behaviour as the definitions of the term grammar above showed. The most frequent concept named in the corresponding definitions is that of 'propriety/proper'. To repeat, it must be emphasized that this notion is social in meaning, not necessarily language-based. This is very apparent if we consider the definitions in a) and b) below, which, in addition to the formulaic definitions, were presented in rhyming couplets for entertaining and mnemonic reasons.

a) Grammar, by proper Rules laid down, does teach / The strict Proprieties of ev'ry Speech; / Instructs to speak, or read, with proper grace, / To write correct; and elegance to trace [...]. (Smetham 1774: 103)

b) Grammar, that useful, ornamental Art, / Does Rules to speak, \& read, and write, impart. (Francis 1790: 45)

It is noteworthy that the concept of 'propriety' in both examples is likened to grace, elegance and ornament, i.e., terms belonging to the word field of 'attractiveness', 'refinement', and 'neatness'. Thus, conduct and appearance serve as general focus points when explaining the concept of 'proper language'.

In example c), the author starts off his treatise with a comparison that relates to the opposite of the wished-for, appropriate language usage:

c) For as an uncouth, ambiguous, imperfect Language, is a sure Sign of a slothful or low Genius in the People; a Language that is copious and clear, and easy, shews a good Understanding and Capacity, and hath many Advantages which are very valuable. (Wilson 1724:4) 
It can be taken for granted that this specific instance of comparison was implicitly given in most grammars. It can also be found in the editorial composition of works that are labelled as grammatical treatises. John Ash's 1786 edition of Grammatical Institutes contains an additional chapter called "Select Lessons, to instil just Sentiments of Virtue into Youth". They were meant to help develop, for example, "solid glory and real greatness", "true politeness", "justice" and "Christian fortitude" (Ash 1786: 165-169). This case, like other explicit statements, is indicative of the continuous association of correct language usage with propriety. All the more so, if it is borne in mind that it is precisely the following meaning of proper that surfaced at the beginning of the eighteenth century and dominated the word's semantics throughout this century: 'conforming to recognized social standards or etiquette; decent, decorous, respectable, seemly' (see OED 2020).

All eighteenth-century grammars follow a pedagogical agenda. Most, if not all, of them were meant to be used as textbooks for teachers of the subject, or the authors themselves were teachers who put together what they thought was essential for their own purposes. Whatever the concrete motivation and whatever the education goal, authors needed to be very descriptive when detailing problems, phenomena, etc. The longer passage in d) is taken from Thomas Smetham's The Practical Grammar:

d) Great differences have arisen among grammarians and teachers, concerning the proper manner of pronouncing the letter $a$. Many insist that it ought to be pronounced broad, according to the Scotch manner of speaking; though contrary to the practice and opinion of the best orators, and most elegant speakers; when, if they did but examine into the matter, they would find, that the broad sound of the vowel $a$ is the very thing which appears so disagreeable to the ear of such as converse with the Scotch. The learned Doctor Johnson tells us, that a has three sounds; namely, slender, open, and broad. The slender is the true English sound; as in face, mane, \&c. and in all words ending in ation; as creation, multiplication, \&c. The open is the Italian $a$; as in father, fancy, glass, \&c. The broad is the German $a$; in wall, call, \&c. Those teachers who would instruct their pupils to pronounce the letter $a$ according to the Scotch mode, which is the disagreeable broad sound borrowed from the Germans, should recollect that they will insensibly bring them to that disagreeable, pedantic, and ridiculous manner of speaking, commonly called the Scotch drawl; for, according 
to their customary manner of speaking, the word cake would be called cauke; bake, bauke; candle, caundle; caper, cauper, \&c. when they might with equal propriety change the other English vowels into French and German vowels [...]. (Smetham 1774: 37-38)

Two points are illustrated. First, it shows how authors turn to comparative descriptions that involve references to other languages when describing contemporaneous phenomena observed in the speech of fellow English-speakers: their usage is described as an "open Italian" or "broad German" vowel. Second, the passage reveals that authors associate desired language behaviour with favourable qualities and undesired language behaviour with devaluations. This is seen in the underlined sequences (please note that italics are kept as in the original).

Whether wholly prescriptive or almost formally descriptive, whether pejoratively evaluating or naively assuming, all eighteenth-century grammars can be seen as means in the emancipation process of the vernacular language English vis-à-vis the universal language Latin. Raising the status of English, this process also involved debates questioning the applicability of grammatical description to languages such as English. The quantity and the quality of eighteenth-century grammars give evidence that this was no longer a question for the authors. Their almost unequivocal view that English could be captured by contemporaneous grammatical concepts and should also be taught accordingly often coincided with patriotic expressions:

e) It is the glory of the English to understand their own language: we cannot begin too early to lay a good foundation in this." (Rhodes 1795: vi; my emphasis)

f) I am not so insensible of the Advantages of the dead Languages, as to discourage the teaching of them at a proper Time; but this I am willing to maintain, that the Study of our own, ought to precede that of all others [...]. (Hodgson 1770: v-vi; my emphasis)

The opinion observable in e) and f) above was also present in grammars of the first half of the eighteenth century. In grammars of the early decades of the eighteenth century, however, authors had to address the applicability of grammatical concepts and categories to English. In order to support their argument that, of course, grammar can be applied to English, authors make 
use of expressions that represent the impossibility to apply grammar to a language as barbarity:

g) Youths are [...] hurried into Latin, before they are well able to read English: as if this last were so despicable, that it needed not, or so barbarous, that it could not be digested into a Grammatical Method. (Mattaire 1712: iii-iv)

Again, I should like to emphasize that throughout the second half of the eighteenth century authors no longer had to argue in favour of English grammar. Yet, they still needed to challenge priorities in education, presenting Latin, for example, as dead, useless, puzzling, or absurd:

h) [Let students] acquire a masterly and critical Knowledge of their own Language! which has been so amazingly sacrificed and neglected for a smattering in Latin and Greek, with which, after they have mispent so much precious Time, they are to hold no more Correspondence than with the Chinese! ... Notwithstanding I may appear to be animated with a more than ordinary, tho' I hope, becoming Zeal in the Cause of a proper English Education, and cannot give my Assent to the whole of a young Gentleman's Time being engrossed and sacrificed to a dead Verbality [...]. (Buchanan 1762: xvii)?

i) A practice still more ridiculous has universally prevailed, till very lately, in all our schools; that of straining the English Tongue, without any reason or necessity, to be subservient to the puzzling rules, exceptions, and intricacies, of the Latin Grammar; by which the mind is incumbered with innumerable unnecessary distinctions [...]. (Smetham 1774: iii)

j) The utility of an English education has induced many to write [...] the importance or significancy thereof, is now pretty well understood, and the absurdity of young pupils learning the Latin language, or any other, in preference to their own, has been so sufficiently pointed out as to render a repetition of that sort quite unnecessary. (Hornsey 1793: 3)

The support of the English language and the elevation of its status are not just carried by debasing statements about Latin. The latter are complemented by subjective comparisons leading to the equation of (natural) beauty with the English language. John Ash, for instance, would like young pupils to gain an "intimate Acquaintance with the Proprieties and Beauties of the English 
Tongue" because it "would be [...] desirable and necessary [and] far preferable to a Smattering of the learned Languages" (Ash 1761: iii). It is noteworthy that the notion 'propriety' is coordinated with 'beauty'. These expressions are also quite central in the conclusion of Thomas Smetham's explanation of why, in his view, English is not only a vernacular applicable to grammar and capable of outstanding communication (see l) below). This explanation is preceded by an enumeration of stereotypical comparisons in $\mathrm{k}$ ). There, various languages are presented according to alleged perceptions as follows:

k) The Hebrew hath been called the most emphatical language in the world; the Greek, the most lofty; the Latin, the most majestic; the Italian, the most soft; the Spanish, the most noble; and the French, the most polite. In the English are happily united the emphatical expression of the Hebrew, the sublimity of the Greek, the majesty of the Latin, the softness of the Italian, the nobleness of the Spanish, and the politeness of the French. Besides, it is not so confined as the Hebrew, so irregular as the Greek, so unequal as the Latin, so effeminate as the Italian, so precise as the Spanish, nor so volatile as the French. (Smetham 1774: vi)

l) In the English Tongue we may, with propriety, address God with the spirit of adoration, Monarchs with the spirit of freedom, Neighbours, with the warmth of friendship, and Beauty with the softness of persuasion. (Smetham 1774: vi-vii)

This stream of comparisons culminates in a statement that, again, ascribes unrivalled verbal expressibility to beauty and, thus, claims the superiority of English over all other languages worth mentioning:

m) The English Language owes its excellency to its being a composition of the most heterogeneous ingredients; a medley of innumerable other languages. The beauties of almost every tongue have been selected to grace ours; and, with few or none of the defects of any, to present us with the charms of all. (Smetham 1774: vii)

It is intriguing that, at the beginning of the eighteenth century, there are authors who also claim superiority for English, but try to deny the linguistic facts of English being heavily influenced and altered by language contact. Indeed, they strive for a 'pure' English that does not "want any foreign Help to 
express the nicest Sense out of its own Store" (Gildon/Brightland 1711: [iii]). They are in contrast to Smetham who appears to take delight in the hybridity of English leading to the language's superiority. Gildon and Brightland were clearly not of that opinion. They admit, yet disapprove that English "receiv'd innumerable Shoals of stranger words" and chauvinistically conclude that "to carry this Humour still on, is to Debase, not Advance, our Native and Masculine Tongue" (Gildon/Brightland 1711: [iii]). Whether they would have changed their views, had they been of Smetham's generation is a mute point. It needs to be added, however, that Smetham is not necessarily an isolated case. Yet, other authors appear to have taken a more objective perspective towards the described developments:

n) $[\mathrm{M}]$ any Norman words and phrases were by degrees blended with the Saxon, tho' it's general form and construction still remained the same. From the Conquest to the Reformation, our language continued to receive occasional supplies of foreign words. Our terms of dress we borrowed from the Italians; those of War and Cookery from the French; our commercial words were chiefly imported from Lombardy; and those of Navigation from Holland. In addition to these the learned have enriched it with many significant expressions drawn from the treasures of Greek and Latin literature, by which means our language has acquired such a degree of strength and copiousness, that it is able to express every subject with elegance and accuracy. (Bullen 1797: 138)

It also needs to be added that the presentation of English as an excellent, if not superior, language is no novelty of the second half of the eighteenth century. We already find authors at the beginning of the eighteenth century who maintain similar ideas and concepts:

o) Now since no Language in the World seems more capable of having all manner of Learning treasur'd up in it, than our English Tongue; why may we not [...] set up Grammar, Rhetoric, and Philosophy Schools in our Mother-Tongue, that Foreiners abroad may covet to learn our Language [...]. (Lane 1700: xviii) 
The wording is less pompous and certainly much clearer in its expression. To A. Lane, eloquence is not only a desirable behaviour. It is a skill that is likened to naval and military skills:

p) Leaders and Commanders, both by Sea and Land, [...] who by their Learning, Civility and Eloquence in their Mother-Tongue, [would enlarge] their Dominions no less than by their Arms. (Lane 1700: xix; my emphasis).

So language becomes a valuable weapon, or at least a further means to enlarge the spheres of influence of a country that was to become a world power.

To end this subchapter, the following comment shall be permitted. It is surprising and, at the same time, it is not surprising that there is no mention of languages which existed side by side with English across Britain and Ireland. In the eighteenth century, all of them, i.e., Cornish, Gaelic, Irish, Manx and Welsh were still very much living languages. A lack of knowledge and awareness cannot be assumed. The treatises of MacCurtin (1728), Richards (1753), Walters (1771), Vallancey (1773) and Pryce (1790) show too clearly that there must have existed an awareness of and perhaps a genuine interest in the Celtic languages of Great Britain and Ireland. The publication of said works can certainly be seen as an honest acknowledgment of the fact that the archipelago was multilingual. Given that, it is not right to associate the progress of eighteenth-century English with relentless imperial expansion at the expense of Cornish, Gaelic, Irish, Manx and Welsh. Yet, it is right to assume that the progress of English went hand in hand with neglectful behaviour towards the neighbouring languages foreshadowing the nationalism that was to take root in England and elsewhere in the following century. It is also right to add that the development towards strong national(ist) sentiments had already started in the previous century: "[O]ur own Language is to bee esteemed a chief part of the honor of our Nation, which wee all ought to our utmost power, to advance." (Wharton 1655: [To the reader])

\section{Conclusion}

This contribution set out to study practices of comparing in eighteenth-century grammars of English. The examination of which has added to what is consensus among scholars of (eighteenth-century) English grammaticogra- 
phy: "Behind a superficial appearance of uniformity, imitativeness and dullness the English grammars in fact contain a most surprising diversity of outlook and of categories. This diversity is new and important evidence, but can be adequately displayed only by extensive quotation" (Michael 1970: 2).

Having looked at various examples of intra-cultural as well as intercultural comparison, it appears that they help to demonstrate what is meant to be taught, to describe what is desired language behaviour, to explain that English deserves its place in the educational canon, and to maintain that the excellency of the English language is the result of its meandering history.

With regard to two more instances in the primary material, it can be concluded with confidence that practices of comparing can be read as heralds of the discourse of linguistic nationalism and as harbingers of language philosophy: "By the aid of Language we study the ideas of others; we compare opinions with opinions; and improve upon the comparison. Our understanding is expanded, our passions refined, our vices corrected, and our virtues improved." (Smetham 1774: i) In very few cases of which Priestley certainly is an outstanding example, practices of comparing can also be read as precursors of descriptive linguistics:

Grammar may be compared to a treatise of Natural Philosophy; the one consisting of observations on the various changes, combinations, and mutual affections of words; and the other of the parts of nature: and were the language of men as uniform as the works of nature, the grammar of language would be as indisputable in its principles as the grammar of nature: but since good authors have adopted different forms of speech, and in a case that admits of no standard but that of custom, one authority may be of as much weight as another; the analogy of language is the only thing to which we can have recourse, to adjust these differences; for language, to answer the intent of it, which is to express our thoughts with certainty in an intercourse with one another, must be fixed and consistent with itself. (Priestley 1761: vi)

Yet, this paper's scope was too limited to be able to state whether practices of comparing were motors of arriving at descriptive grammaticography. Nevertheless, they were undoubtedly an integral part of the methodological makeup of eighteenth-century grammars and must therefore be understood as a convention within the discourse tradition of grammar-writing. 


\section{Bibliography}

\section{Primary Sources ${ }^{3}$}

A., M. The Elementary Principles of English Grammar. Bridport: S. Margrie, 1785. Adam, Alexander. The Principles of Latin and English Grammar. Edinburgh: A. Kincaid and W. Creech, 1772.

A New English Grammar. London: no publisher, 1746.

Ash, John. Grammatical Institutes. 4th ed. London: E. \& C. Dilly, 1761.

Ash, John. Grammatical Institutes. A new edition, revised, corrected, and enlarged. London: Charles Dilly, 1786.

A Short English Grammar. London: C. Dilly, 1794.

Bicknell, Alexander. The Grammatical Wreath. London: A. Bicknell, 1790.

Brightland, John. A Grammar of the English Tongue. London: Mr. Guy et al., 1712. Brittain, Lewis. Rudiments of English Grammar. Louvain: L. J. Urban, 1788.

Buchanan, James. The British Grammar. London: A. Millar, 1762.

Buchanan, James. An Essay towards Establishing a Standard for an Elegant and Uniform Pronunciaton of the English Language. London: Edward \& Charles Dilly, 1766.

Bullen, John. Rudiments of English Grammar. London: P. Gedge, 1797.

Burn, John. A Practical Grammar of the English Language. Glasgow: Archibald McLean, 1766.

Chown, William. English Grammar Epitomised. Northampton: T. Dicey, 1788.

Coar, Thomas. A Grammar of the English Tongue. London: James Phillips, 1796.

Corbet, John. A Concise System of English Grammar. Shrewsbury: T. Wood, 1784.

Devis, [Ellen]. The Accidence. London: J. Beegroft et al., 1775.

Dilworth, Thomas. A New Guide to the English Tongue. 37th ed. London: T. Moore, 1783.

Eves, [Mrs.]. The Grammatical Play-Thing. Birmingham: T.A. Pearson, 1800.

Farro, D. The Royal Universal British Grammar and Vocabulary. London: J. Hodges, 1754.

Fenning, Daniel. A New Grammar of the English Language. London: S. Crowder, 1771.

3 Unless otherwise stated, all primary texts have been available as facsimile pdf-files in the Eighteenth-Century Collections Online at https://www.gale.com/intl/primary-sour ces/eighteenth-century-collections-onlines between November 2019 and March 2020. 
Francis, William. A Concise Introduction to English Grammar. Marlborough: E. Harold, 1790.

Gardiner, Jane. The Young Ladies' English Grammar. York: T. Wilson \& R. Spence, 1799.

Gildon, Charles \& John Brightland. A Grammar of the English Tongue. [Facsimile Reprint]. Menston: The Scolar Press, 1967 [1711].

Gough, James. A Practical Grammar of the English Tongue. 2nd ed. Dublin: I. Jackson, 1760 .

Greenwood, James. An Essay Towards a Practical English Grammar. London: R. Tookey, 1711.

Greenwood, James. The Royal English Grammar. London: J. Nourse, 1737.

Hodgson, Isaac. A Practical English Grammar. London: B. Law, 1770.

Hornsey, John. A Short English Grammar. York: Wilson, Spence and Mawman, 1793.

Jones, Hugh. An Accidence to the English Tongue. London: John Clarke, 1724.

Kenrick, William. A New Dictionary of the English Language. London: John and Francis Rivington et al., 1773.

Kitson, Roger. A Short Introduction to English Grammar. Norwich: Stevenson \& Matchett, 1798.

Lane, A. A Key to the Art of Letters. London: J. Churchill et al., 1700. Accessed via Early English Books Online, 26 March 2020. «ttp://eebo.chadwyck.com /homes.

Lougthon, William. A Practical Grammar of the English Tongue. London: Cæsar Ward \& Richard Chandler, 1734.

Lowth, Robert. A Short Introduction to English Grammar. London: J. Hughs, 1762. MacCurtin, H. The Elements of the Irish Language. Lovain: Martin van Overbeke, 1728.

Maittaire, Michael. The English Grammar. London: W. B. for H. Clements, 1712. Metcalfe, Lister. The Rudiments of the English Tongue. 2nd ed. Newcastle: T. Saint, 1771.

Murray, Alexander. An Easy English Grammar. 2nd ed. London: B. Law, 1787.

Murray, Lindley. English Grammar. [Facsimile reprint] Ed. R.C. Alston. Menston: The Scolar Press, 1968 [1795].

Postlethwaite, Richard. The Grammatical Art Improved. London: J. Parsons, 1795. Priestley, Joseph. The Rudiments of English Grammar. London: R. Griffiths, 1761. Pryce, William. Archceologia Cornu-Britannica; or, an Essay to Preserve the Ancient Cornish Language. Sherborne: W. Cruttwell, 1790.

Raine, Matthew. English Rudiments. Darlington: John Sadler, 1771. 
Rhodes, Benjamin. A Concise English Grammar. Birmingham: J. Belcher, 1795. Richards, Thomas. Introduction to the Ancient British, or Welsh Language. Bristol: Felix Farley, 1753.

Sheridan, Thomas. British Education. Dublin: George Faulkner, 1761.

Smetham, Thomas. The Practical Grammar. London: J. Cooke, 1774.

Vallancey, Charles. A Grammar of the Iberno-Celtic, or Irish Language. Dublin: R. Marchbank, 1773.

Walters, John. A Dissertation on the Welsh Language. Cowbridge: J. R. and D. Thomas, 1771.

Ward, H. A Short, but Clear System of English Grammar. Whitehaven: [n.p.], 1777. Webster, Noah. Rudiments of English Grammar. Hartford: Elisha Babcock, 1790. Wharton, Jeremiah. A New English Grammar. London: W. Dugard, 1655.

Wilson, Thomas. The many Advantages of a Good Language to Any Nation. London: J. Knapton, etc., 1724.

\section{Secondary Sources}

Alston, R. C. A Bibliography of the English Language from the Invention of Printing to the Year 1800. Vol. 1: English Grammars Written in English and English Grammars Written in Latin by Native Speakers. Leeds: E. J. Arnold \& Son, 1965.

Baugh, Albert C. A History of the English Language. 2nd ed. London: Routledge \& Kegan Paul, 1959.

Beal, Joan C. English in Modern Times 1700-1945. London: Arnold, 2004.

Beal, Joan C. "Prescriptivism and the Suppression of Variation." EighteenthCentury English. Ideology and Change. Ed. Raymond Hickey. Cambridge: Cambridge University Press, 2010. 21-37.

Bloomfield, Morton W. and Leonard Newmark. A Linguistic Introduction to the History of English. New York: Alfred A. Knopf, 1963.

Coseriu, Eugenio. “'Historische Sprache' und 'Dialekt'." Energeia und Ergon. Sprachliche Variation - Sprachgeschichte - Sprachtypologie. Vol. I: Schriften von Eugenio Coseriu (1965-1987). Ed. Jörn Albrecht. Tübingen: Gunter Narr, 1988. 45-61.

Emsley, Bert. "James Buchanan and the Eighteenth-Century Regulation of English Usage." Publications of the Modern Language Association 48 (1933): 11541166.

Foucault, Michel. L'ordre du discours. Leçon inaugurale au Collège de France prononcée le 2 décembre 1970. Paris: Gallimard, 1971. 
Fens-de Zeeuw, Lyda. Lindley Murray (1745-1826), Quaker and Grammarian. Utrecht: Landelijke Onderzoekschool Taalwetenschap, 2011.

Görlach, Manfred. Eighteenth-Century English. Heidelberg: Universitätsverlag C. Winter, 2001.

Hickey, Raymond. "Attitudes and Concerns in Eighteenth-Century English." Eighteenth-Century English. Ideology and Change. Ed. Raymond Hickey. Cambridge: Cambridge University Press, 2010. 1-20.

Hodson, Jane. "The Problem of Joseph Priestley's (1733-1804) Descriptivism." Historiographia Linguistica 33 (2006): 57-84.

Koch, Peter. "Diskurstraditionen: $\mathrm{zu}$ ihrem sprachtheoretischen Status und ihrer Dynamik." Gattungen mittelalterlicher Schriftlichkeit. Ed. Barbara Frank, Thomas Haye, and Doris Tophinke. Tübingen: Gunter Narr, 1997. 43-79.

Leonard, Sterling A. The Doctrine of Correctness in English Usage 1700-1800. Madison: University of Wisconsin, 1929.

McArthur, Tom. "On the Origin and Nature of Standard English." World Englishes 18 (1999): 161-169.

Michael, Ian. English Grammatical Categories and the Tradition to 1800. London: Cambridge University Press, 1970.

OED. Oxford English Dictionary. Oxford University Press, 2020. Accessed online, 26 March 2020. 〈http://www.oed. com/〉.

Oesterreicher, Wulf. "Zur Fundierung von Diskurstraditionen." Gattungen mittelalterlicher Schriftlichkeit. Ed. Barbara Frank, Thomas Haye, and Doris Tophinke. Tübingen: Gunter Narr, 1997. 20-41.

Rivers, Isabel and David L. Wykes. Joseph Priestley, Scientist, Philosopher, and Theologian. Ed. Isabel Rivers and David L. Wykes. Oxford: Oxford University Press, 2008.

Robins, Robert H. "The Evolution of English Grammar Books since the Renaissance." The English Reference Grammar. Language and Linguistics, Writers and Readers. Ed. Gerhard Leitner. Tübingen: Max Niemeyer, 1986. 292-306.

Romaine, Suzanne. "Introduction." The Cambridge History of the English Language. Vol. IV: 1776-1997. Ed. Suzanne Romaine. Cambridge: Cambridge University Press, 1998. 1-56.

Schlieben-Lange, Brigitte. Traditionen des Sprechens. Elemente einer pragmatischen Sprachgeschichtsschreibung. Stuttgart: Kohlhammer, 1983.

Stammerjohann, Harro. Lexicon Grammaticorum. A Bio-Bibliographical Companion to the History of Linguistics. 2nd ed., revised and enlarged. Ed. Harro Stammerjohann. Tübingen: Max Niemeyer, 2009. 
Straaijer, Robin. Joseph Priestley, Grammarian: Late Modern English Normativism and Usage in a Sociohistorical Context. Utrecht: Landelijke Onderzoekschool Taalwetenschap, 2011.

Sundby, Bertil, Anne Kari Bjørge, and Kari E. Haugland. A Dictionary of English Normative Grammar 1700-1800. Amsterdam: John Benjamins, 1991.

Tieken-Boon van Ostade, Ingrid. Two Hundred Years of Lindley Murray. Ed. Ingrid Tieken-Boon van Ostade. Münster: Nodus Publikationen, 1996.

Tieken-Boon van Ostade, Ingrid. "Lowth's Corpus of Prescriptivism." To Explain the Present. Studies in the Changing English Language in Honour of Matti Rissanen. Ed. Terttu Nevalainen and Leena Kahlas-Tarkka. Helsinki: Société Néophilologique, 1997. 451-463.

Tieken-Boon van Ostade, Ingrid. "Eighteenth-Century Prescriptivism and the Norm of Correctness." The Handbook of the History of English. Ed. Ans van Kemenade and Bettelou Los. Malden: Blackwell, 2006. 539-588.

Tieken-Boon van Ostade, Ingrid. Grammars, Grammarians and Grammar Writing in Eighteenth-Century England. Ed. Ingrid Tieken-Boon van Ostade. Berlin: Mouton de Gruyter, 2008.

Tieken-Boon van Ostade, Ingrid. "Lowth as Icon of Prescriptivism." EighteenthCentury English. Ideology and Change. Ed. Raymond Hickey. Cambridge: Cambridge University Press, 2010. 73-88.

Tieken-Boon van Ostade, Ingrid. The Bishop's Grammar: Robert Lowth and the Rise of Prescriptivism. Oxford: Oxford University Press, 2011.

Vorlat, Emma. Progress in English Grammar 1585-1735. A Study of the Development of English Grammar and of the Interdependence among the Early English Grammarians. 4 Vols. Luxembourg: Pfeiffer, 1964.

Watts, Richard J. "Justifying Grammars. A Socio-Pragmatic Foray into the Discourse Community of Early English Grammarians." Historical Pragmatics. Pragmatic Developments in the History of English. Ed. Andreas Jucker. Amsterdam: John Benjamins, 1995. 145-185.

Watts, Richard J. "Mythical strands in the ideology of prescriptivism." The Development of Standard English 1300-1800. Theories, Descriptions, Conflicts. Ed. Laura Wright. Cambridge: Cambridge University Press, 2000. 29-48.

Watts, Richard J. "Grammar Writers in Eighteenth-Century Britain: A Community of Practice or a Discourse Community?" Grammars, Grammarians and Grammar-Writing in Eighteenth-Century England. Ed. Ingrid TiekenBoon van Ostade. Berlin: Mouton de Gruyter, 2008. 37-56.

Wolf, Göran. Englische Grammatikschreibung 1600-1900 - Der Wandel einer Diskurstradition. Frankfurt/Main: Peter Lang, 2011. 